\title{
PEMIMPIN HUMAN CAPITAL 4.0 DAN KEPEMIMPINAN GLOBAL DI ERA MILENIAL
}

\author{
Yakob Tomatala \\ Sekolah Tinggi Teologi Jaffray Jakarta
}

\begin{abstract}
Leadership is a universal attribute that can be found practically in many situations and all walks of life that involves communities and various different types of culture. Within this context, a Leader have the most important role in the area of organization related leadership, with a task and role to determine the success and or failure of the organization he or she is leading. So the question that needs to be asked within this context is, what kind of Leader and leadership that is relevant in leading an organization in the XXI Century for the Millennial Generation? In order to answer this question, this article is given the title Human Capital 4.0 Leader and Global Leadership in the Millennial Era, outlines an idea that leadership and Leaders that is relevant for the Millennial Era is the type of leadership that gives an example of a Leader who is also an entrepreneur, have the qualification and understanding in the area of Human Capital 4.0, where these ideas will be discussed further within two main topics, which is : First, A Leader Who Also an Entrepreneur, and Two, Global Leadership and a Human Capital 4.0 Leader in the Millennial Era.
\end{abstract}

Keywords: Entrepreneur, global leadership, human capital 4.0, leader, leadership, and leader

\begin{abstract}
ABSTRAK
Kepemimpinan adalah gejala universal yang dapat ditemukan di segala tempat, dan semua waktu, dalam semua bentuk masyarakat dan kebudayaan. Dalam kaitan ini, Pemimpin memiliki tempat yang utama dalam kepemimpinan, dengan tugas dan peran yang menentukan keberhasilan atau kegagalan organisasi yang dipimpinnya. Dalam hubungan ini dipertanyakan, kepemimpinan dan Pemimpin macam apa dan macam bagaimana yang diperlukan dalam memimpin organisasi pada Abad XXI bagi Generasi Milenial? Menjawab pertanyaan dimaksud, tulisan yang berjudul Pemimpin Human Capital 4.0 dan Kepemimpinan Global di Era Milenial, mengetengahkan gagasan bahwa kepemimpinan dan Pemimpin yang dibutuhkan pada Era Milenial ini adalah kepemimpinan global dengan Pemimpin kompeten berjiwa entrepreneur, berkualifikasi Human Capital 4.0, yang dituangkan dalam dua pokok, yaitu: Pertama, Pemimpin Kompeten Berjiwa Entrepreneur; Kedua, Kepemimpinan Global dan Pemimpin Human Capital 4.0 dalam Era Milenial.
\end{abstract}

Kata Kunci: Entrepreneur, gepemimpinan, kepemimpinan global, pemimpin, dan pemimpin human capital 4.0.

18 Korespondensi mengenai artikel dapat dilakukan kepada: Yakob Tomatala, Sekolah Tinggi Teologi Jaffray Jakarta, Jln. Jatinegara Timur No.35, Jakarta Timur (13350), Indonesia

E-mail Corresponding: tomatala.yakob@gmail.com 


\section{PENDAHULUAN}

Kepemimpinan adalah suatu gejala universal dari kehidupan umat manusia (Bass, 1985). Fakta ini menegaskan bahwa di mana ada kehidupan manusia sebagai suatu kelompok, di situ kepempinan ada, diperlukan, dan menjadi penting. Dalam kepemimpinan, komponen Pemimpin memiliki tempat yang sentral dan penting di mana keberadaan dan kinerjanya menentukan maju-mundur, serta jatuh-bangunnya suatu dan semua organisasi. Prinsip ini ditegaskan dalam Amsal 11:14 yang menekankan, "Jikalau tidak ada pimpinan, jatuhlah bangsa tetapi jikalau penasihat banyak, keselamatan ada". Kebenaran ini menegaskan bahwa Pemimpin sepenuhnya ada untuk organisasi dan ada untuk orang-orang yang dipimpinnya.

Dalam kaitan ini, pemimpin sepenuhnya bertanggung jawab untuk mendatangkan serta menghadirkan kemaslahatan bagi semua pihak dalam kepemimpinan yang diembannya. Menyimak prinsip ini, maka timbul pertanyaan, kepemimpinan model apa, dan macam mana serta Pemimpin seperti apa yang dibutuhkan dalam memimpin organisasi pada masa kini, sehingga dapat mewujudkan idealisme ini?

Mengutarakan observasi dan keprihatinannya tentang kondisi pemimpin dan kepemimpinan masa kini, Eka Darmaputera mengatakan, "Pemimpinpemimpin kita banyak, tetapi mereka tidak memimpin. Pemimpin-pemimpin itu seperti tutur Yehezkiel, minum susu dan makan daging domba-domba gembalaan mereka. Tapi tidak membebat luka-luka mereka. Tidak mengarahkan perjalanan mereka. Pendek kata, tidak memedulikan kesejahteraan mereka. Bukankah begitu, lebih kurang, situasi kita saat ini”? (Darmaputera, 2011: 9-10).

Memperhatikan observasi Eka Darmaputera, maka diskursus ini akan mengetengahkan dua pokok penting, antara lain yaitu: Pertama, Pemimpin Kompeten Berjiwa Entrepreneur; Kedua, Kepemimpinan Global dan Pemimpin Human Capital 4.0 dalam Era Milenial; yang diakhiri dengan suatu kesimpulan.

\section{METODE PENELITIAN}

Dalam mengembangkan pokok ini, maka pendekatan yang digunakan adalah metode analisis studi literatur. Pemanfaatan metode analisis studi literatur ini diawali dengan menghimpun data serta menetapkan fakta seputar pokok inti tentang pemimpin, kepemimpinan, kepemimpinan global, entrepreneur, human capital 4.0 (HC 4.0), dan human being empowerment (HBE) dari literatur-literatur yang tersedia. Dari literatur-literatur ini, dikembangkan pokok utama diskusi tentang "Pemimpin Human Capital 4.0 dan Kepemimpinan Global di Era Milenial" yang merupakan domain umum dari kajian ini.

Domain umum ini kemudian dibagi ke dalam dua sub-domain, yang melibatkan pokok-pokok: Pertama, Pemimpin kompeten berjiwa entrepreneur;

19 | Komitmen Mahasiswa Manajemen Pendidikan Kristen dalam..., Tomatala, Yakob

Jurnal Christian Humanioran | http://e-journal.iakntarutung.ac.id/index.php/humaniora 
dengan gagasan-gasan spesifik yang terkait. Kedua, Kepemimpinan Global dan Pemimpin Human Capital 4.0 dalam era milenial; yang menyentuh aspek-aspek khusus dari pokok-pokok ini. Diskusi tentang pokok-pokok dimaksud dilakukan dalam dua tahap, memakai pendekatan analisis domain, untuk memilih, merinci, memeriksa dengan berpikir ketat guna memperoleh arti dan makna dari setiap gagasan, yang kemudian menarik kesimpulan dengan menetapkan proposisiproposisi temuan dari pokok-pokok kajian dimaksud.

\section{HASIL DAN PEMBAHASAN}

\section{Hasil Diskusi Pertama}

\section{Pemimpin Kompeten Berjiwa Entrepreneur}

Ilmu Kepemimpinan memiliki tiga lingkup kajian utama, yang meliputi: Satu, Elemen Dasar Kepemimpinan. Dalam Elemen Dasar Kepemimpinan, terdapat tiga komponen, yaitu: 1) Pemimpin; 2) Orang Yang Dipimpin; dan 3) Situasi Keorganisasian. Dari ketiga komponen ini, faktor Pemimpin sangat menentukan kadar kualitas serta efektivitas, efisiensi, kesehatan, optimalisasi, produktivitas, dan sukses kinerja kepemimpinan.

Dua, Doktrin Dasar Kepemimpinan. Unsur Doktrin Dasar Kepemimpinan melibatkan dua komponen, yaitu: 1) Perlengkapan Dasar Kepemimpinan, dengan aspek-aspek: a) Perilaku serta Gaya Kepemimpinan (Leadership Behavior and Style); dan b) Alat Perlengkapan Kepemimpinan, yaitu Sumber-sumber (Leadership Resources) yang melibatkan unsur: Men, Machine - Technology, Materials, Money, Market, Moment, Management System, Methods, and Main Infrastructures (9 M). 2) Nilai-nilai Dasar Kepemimpinan (Leadership Values), yang meliputi Nilai Teologis dan Nilai Filosofis.

Tiga, Pekerjaan atau Tugas Kepemimpinan. Unsur Pekerjaan atau Tugas Dasar Kepemimpinan, meliputi komponen (1) Esensi Tugas (Tugas Dasar, Tugas Utama dan Tugas Pendukung); (2) Sifat Tugas; (3) Unsur Ekonomi Tugas; dan (4) Unsur Lingkungan Tugas (Tomatala, 2011). Selanjutnya, dalam mengembangkan diskursus pada bagian ini, ada dua hal penting yang akan didiskusikan. Kedua hal tersebut antara lain adalah: Pertama, Mencari Pemimpin Kompeten; dan Kedua, Mengembangkan Pemimpin Kompeten yang Berjiwa Entrepreneur.

Pertama, Mencari Pemimpin Kompeten. Telah dijelaskan di atas, bahwa komponen Pemimpin sangatlah dominan dalam kepemimpinan. Dengan demikian, dapatlah dikatakan bahwa keberhasilan atau kegagalan kepemimpinan, sangat ditentukan oleh Pemimpin. Karena itu, sangatlah diperlukan adanya Pemimpin kompeten, bagi tugas kepemimpinan pada semua organisasi. Istilah "kompeten dan kompetensi" (International Dictionary of English Language, 1976), yang digunakan di sini, berasal dari kata "competent" < competens, competere (Latin) yang berarti "menjadi penuh atau lengkap sehingga dapat menjawab kebutuhan atau tuntutan." 
Kompetensi yang memenuhi kebutuhan dan tuntutan yang dimaksudkan di sini meliputi faktor-faktor: 1) memenuhi semua persyaratan, cocok, puas dan memadai untuk suatu tujuan tertentu. 2) Memenuhi semua kualifikasi dan kapasitas yang dituntut untuk mengerjakan suatu pekerjaan atau tugas. 3) Sangat sesuai untuk mengerjakan suatu pekerjaan, dan 4) Telah memenuhi semua ketentuan dan tuntutan untuk menjadi kompeten bagi suatu pekerjaan. Dengan demikian, pengertian ini menjelaskan bahwa "Pemimpin kompeten adalah seseorang yang telah mencapai kualifikasi dan kapasitas, serta memiliki potensi lengkap, sehingga menjadi mandiri dan dapat memenuhi persyaratan yang dituntut baik formal, personal, legal, profesional, posisional, dan sosial untuk menjadi, serta melaksanakan tugas memimpin sebagai pribadi mandiri” (Tomatala, 2018).

Selanjutnya, dapat dikatakan bahwa "Pemimpin Kompeten, adalah pribadi mandiri dengan kapasitas dan potensi kepemimpinan yang meliputi: 1) Kompetensi Karakter, yang ditandai aspek INTEGRITAS karakter (Character Integrity), sebagai dasar bagi spiritualitas (spirituality) etika, moral dan etos kepemimpinan (SQ - Spiritual Quotient). 2) Kompetensi Intelegensi, yang melibatkan KAPASITAS Pengetahuan yang bersifat komprehensif dan khas lebih (IQ - Intelligence Quotient - Human Intelligence). 3) Kompetensi Kecakapan kerja, yang ditandai KAPABILITAS andal, meliputi kecakapan sosial, kecakapan entrerpreneur, kecakapan ekonomi, serta kecakapan teknis (SEETQ - Social, Entrepreneur, Economy \& Technical Quotient - Human Skills), sehingga Pemimpin memiliki kualitas dan keandalan memimpin untuk melaksanakan tanggung jawab kepemimpinan secara unggul" (Tomatala, 2018). Kompetensi Pemimpin pada gilirannya menunjukkan kadar mentalitas kepemimpinan yang merupakan faktor yang meneguhkan untuk menjadi andal dalam melaksanakan upaya memimpin.

Kompetensi INTEGRITAS Karakter (Spiritual Quotient - SQ). Secara Lexical, istilah integritas berasal dari kata "integrity" (Latin integritas < integer), yang artinya 'tidak tersentuh' (untouched), atau 'menyeluruh' (whole) atau 'keseluruhan' (entire) (Webster New Universal Dictionary of The English Language, 1976). Dari pemahaman ini dapat ditegaskan bahwa integritas adalah "suatu keadaan atau kualitas kehidupan yang dibangun di atas kebenaran, keadilan, ketulusan dan kejujuran yang lengkap atau penuh, sehingga menyentuh aspek etika (inner values - keadaan dan sikap batin) dan moral (expression of personality) yang berkesesuaian dan konsisten dalam pikiran, sifat, sikap, kata, serta perbuatan (Yesaya 32:1-2; 33:15-16). Individu yang berintegrias memiliki akhlak yang berbudi luhur (Yesaya 32:8; Ayub 28:28) yang menandakan adanya spiritualitas (spirituality) dengan nilai-nilai kehidupannya yang dibangun di atas kebenaran, sebagai landasan bagi kebaikan, keadilan, kejujuran, kesetiaan, kesabaran, kepatuhan dan kepatutan. Nilai-nilai kehidupan berintegritas ini

21 | Komitmen Mahasiswa Manajemen Pendidikan Kristen dalam ..., Tomatala, Yakob

Jurnal Christian Humanioran | http://e-journal.iakntarutung.ac.id/index.php/humaniora 
dihidupi serta disikapi secara sikron dalam pikiran, sikap, kata serta perbuatan (Yesaya 32:1-2; Filipi 4:5, 8-9), ditandai cara hidup beretika, bermoral, beretos dan beretiket mulia, sebagai "pribadi yang dapat dipercaya" (II Timotius 2:2, Kolose 3:18, 23). Faktor integritas karakter dengan nilai-nilai mulia inilah yang merupakan dasar, kekuatan dan kuasa yang akan menopang serta melindungi setiap Pemimpin untuk teguh dan bertahan dalam membaktikan dirinya sebagai Pemimpin andal yang kompeten, mandiri serta kredibel. Faktor integritas ini jugalah yang melindungi Pemimpin sehingga dapat memimpin ke akhir secara baik (finishing well) (Tomatala, 2002), dan "memiliki nama harum" (Pengkhotbah 7:1). Dapat dikatakan bahwa Pemimpin berintegritas sajalah yang dapat menjalankan kepemimpinan dengan adil dan takut akan Allah, sehingga "meneguhkan kehidupan orang yang dipimpin, yang pada gilirannya menggangkat serta meninggikan derajatnya sebagai Pemimpin yang patut dihormati" (Amsal 14:34; 21:21; I Timotius 5:17), karena telah "menjadi berkat bagi banyak orang" dalam kepemimpinan (II Samuel 23:3-4a; Yesaya 32:1-2; Daniel 12:3).”

Kompetensi KAPASITAS Pengetahuan atau Intelegensi (Intelligence Quotient - IQ). Kapasitas inteligensi adalah potensi pengetahuan dengan kemampuan berpikir yang luas (comprehensive) dan khas lebih (specific). Kompetensi intelegensi menjelaskan tentang kadar berpikir (kualitas), keluasan berpikir (cakupan kuantitas), dan sifat berpikir (kritis, kreatif, inovatif, inspiratif dan kontemplatif), yang memberi keandalan berpikir strategis taktis, dan kearifan berpikir, yang menempatkan Pemimpin pada tataran atas dalam kepemimpinan. Potensi intelegensi merupakan indikator kecerdasan berpikir, yang menyebabkan Pemimpin andal memimpin dan berada di depan dari orang lain, khususnya Pemimpin-pemimpin lain serta orang-orang yang dipimpinnya.

Kompetensi KAPABILITAS Sosial, Ekonomi, Entrepreneur, dan Teknis (Social, Economy, Entrepreneur, Technical Quotient - SEETQ). Kompetensi Kapabilitas adalah kompetensi "human skills" (kecakapan manusia) yang melibatkan kecakapan sosial, entrepreneur, ekonomi, dan teknis, yang memberi keandalan bagi Pemimpin melaksanakan upaya memimpin (leading attempt) secara praksis dengan keandalan menggerakkan kerja semua komponen pada segala lini. Kompetensi sosial adalah kecakapan sosial (social skills) ditandai keandalan membangun dan memelihara hubungan sehat yang semakin meluas (social base), dan kecakapan mengelola serta mengatasi masalah (adversity skills) dalam proses memimpin. Kompetensi entrepreneur atau entrepreneur skills adalah "kadar kemandirian Pemimpin", dengan indikator adanya visi, misi, keberanian berpikir (berani berpikir besar) dengan cara kritis, kreatif, inovatif, inspiratif dan kontemplatif; berani memutuskan secara berprioritas (dengan siap menanggung resiko); dan berani bekerja dengan cara khusus (secara efektif, efisien, sehat, optimal dan produktif), sehingga berada di depan pesaing dalam melaksanakan 
upaya memimpin yang membawa sukses kepemimpinan (Tomatala, 2010). Kompetensi ekonomi adalah kecakapan ekonomi (economic skills), yang merupakan keandalan Pemimpin memperhitungkan komponen serta aspek ekonomi eksternal mau pun internal, dan kepiawaian mengelola faktor ekonomi organisasi. Kompetensi ekonomi berhubungan dengan keandalan memanajemeni dan mengelola "semua sumber organisasi" (9 M) mendukung upaya memimpin, sehingga kepemimpinan dapat terlaksana secara efektif (doing the right thing), efisien (doing the right thing rightly), sehat (healthy organization relationship), optimal (optimum) dan produktif (productive). Kompetensi teknis, adalah keandalan memanfaatkan human intelligence dan artificial intelligence menerapkan "kepemimpinan" dengan kecakapan memimpin (leadership skills High Performance Leadeship), kepiawaian "manajemen" (management skills Total Quality Management) dan kemahiran "administrasi” (tasks skills - Task Execution Skills) dalam menata tugas (Tugas Dasar, Tugas Utama, Tugas Pendukung) dan penugasan serta menggerakkan tugas pada level operational yang terlaksana dan bergerak secara sinergis, dan simultan guna mencapai setiap target, memncapai visi dan misi organisasi (Tomatala, 2011).

Kedua, Mengembangkan Pemimpin Kompeten yang Berjiwa Entrepreneur. Istilah entrepreneur telah digunakan secara umum untuk menjelaskan bidang usaha bisnis ekonomi (Tomatala, 2010). Namun dalam pengamatan ditemukan fakta bahwa setiap Pemimpin yang berhasil, sejatinya "berjiwa entrepreneur," yang andal berkiprah dalam semua bidang kerja.

Entrepreneur, entrepreneurship, kewirausahaan. Istilah entrepreneur dan entrepreneurship, berasal dari kata entreprendre (Perancis) yang berarti "menjalankan, yang menjelaskan seseorang yang mengorganisir dan menjalankan suatu usaha secara mandiri dan berani guna memperoleh keuntungan." Sedangkan kata kewirausahaan (wira, artinya berani), adalah suatu model "kepemimpinanmanajemen khusus yang berorientasi kepada kemandirian, yang digunakan untuk menjalankan bisnis dengan mengelola suatu usaha yang dilakukan secara berani dan dijalankan sedemikian rupa, sehingga menghasilkan keuntungan finansial." (Sarosa, 2005:12)

Karakteristik Entrepreneur. Karakteristik entrepreneur secara umum dapat diidentifikasi sebagai berikut: 1) Seorang entrepreneur memiliki VISI yang besar dan jelas (dream big); 2) Seorang entrepreneur memiliki semangat dengan keberanian untuk memulai dari kecil, berani gagal dan berani bangkit lagi (Start Small - from what and where you are), dengan tindakan-tindakan nyata yang harus dimulai sekarang ini juga (Act Now). 3. Seorang entrepreneur adalah pribadi mandiri yang pemberani, yang memiliki: "VISI + KEBERANIAN + SEMANGAT + TINDAKAN = SUKSES." 4) Karakteristik ini menegaskan bahwa Pemimpin yang berjiwa entrepreneur, adalah: a) Seorang entrepreneur

23 | Komitmen Mahasiswa Manajemen Pendidikan Kristen dalam ..., Tomatala, Yakob

Jurnal Christian Humanioran | http://e-journal.iakntarutung.ac.id/index.php/humaniora 
ialah VISIONER yang memiliki VISI besar dan jelas; b) Seorang entrepreneur memiliki KEBERANIAN (keberanian berpikir, bersikap dan bertindak dengan semangat tinggi) untuk mengerjakan suatu USAHA dengan siap menanggung resiko apa pun; c) Seorang etrepreneur memiliki tekad BERTINDAK untuk bekerja dengan CARA TERTENTU guna mencapai keberhasilan. d) Seorang entrepreneur memiliki MENTALITAS INVESTOR, dan kejelian memanfaatkan orang kepercayaan untuk bekerja baginya, mengelola usaha dengan sistem mananajemen khusus yang tepat terap, guna membawa keuntungan finansial. e) Seorang entrepreneur adalah PRIBADI MANDIRI yang memiliki kemandirian dan kebebasan finansial, dengan kemampuan menghimpun sebanyak mungkin uang dari sumber-sumber yang tersedia.

Entrepreneur Kristen (Tomatala, 2019). Berdasarkan Roma 12:8c, entrepreneur Kristen adalah seorang pribadi mandiri yang berjiwa entrepreneur dan karismatik, dengan panggilan kepemimpinan yang jelas, didukung kebiasaan besikap tekun dengan semangat tinggi, guna bekerja keras secara cerdas. Entrepreneur Kristen memiliki karakteristik umum yang sama dengan entrepreneur umum seperti yang telah disinggug di atas. Kesamaan dan perbedaan siginifikan antara entrepreneur Kristen dan entrepreneur umum ialah bahwa keduanya sama berupaya perolehan sebanyak mungkin uang dari berbagai sumber pemasukkan, untuk meneguhkan kemandirian dan kebebasan finansialnya. Perbedaannya adalah tenrterpreneur umum berorientasi kepada keuntungan finansial sebesar-besarnya, sedangkan entrepreneur Kristen melihat pekerjaannya sebagai ibadah yang dijalankan dengan etika moral bersih, yang bertujuan untuk memperoleh sebanyak mungkin uang, guna menolong sebanyak mungkin orang.

\section{Hasil Diskusi Kedua}

\section{Kepemimpinan Global Dan Pemimpin Human Capital 4.0 Dalam Era Milenial}

Mengaitkan uraian sebelumnya tentang Pemimpin Kompeten, bagian ini akan mengintegrasi gagasan kepemimpinan dan Pemimpin berjiwa entrepreneur dengan kualitfikasi Human Capital 4.0 Leader. Mengawali diskursus ini, menurut James MacGregor Burns, "Kepemimpinan adalah salah satu fenomena yang paling banyak diamati dan paling sedikit dipahami di dunia ini." (Bass, 1981). Pernyataan ini menyiratkan bahwa kepemimpinan memiliki kepentingan yang khusus.

Alasan bagi pentingnya kepemimpinan dapat ditegaskan sebagai berikut: 1) Kepemimpinan adalah penting, karena merupakan "suatu seni yang telah lama dimanfaatkan, yang usianya setua umur manusia di bumi." 2) Kepemimpinan adalah penting, karena merupakan suatu gejala universal yang dapat ditemukan di mana saja, yang perannya berususan dengan penyelenggaraan proses kehidupan dalam semua masyarakat. 3) Kepemimpinan adalah suatu pokok kompleks yang 
berurusan dengan semua aspek kehidupan. 4) Kepemimpinan adalah penting, karena sifatnya sebagao suatu ilmu sosial yang lugas dan terbuka serta suatu seni untuk mengatur kehidupan. 5) Kepemimpinan adalah penting, karena perannya yang memperlancar hubungan-hubungan, mencakup interaksi pemimpin, para bawahan dan situasi (lokus sosio-budaya dan kerja). 6) Kepemimpinan adalah penting, karena menyediakan kerangka dan mekanisme yang berurusan dengan sistem, atau masinesasi sosial dengan orientasi kemanusiaan yang memperlancar proses kehidupan organisasi. 7) Kepemimpinan adalah penting, karena berhubungan dengan ilmu pengetahuan (orientasi teoritis dan riset empiris) yang berperan sebagai landasan pengetahuan untuk membangun dan meneguhkan kehidupan bersama sebagai suatu kelompok (semua bentuk organisasi, dan masyarakat, dsb). 8) Kepemimpinan adalah penting, karena memiliki orientasi nilai (value orientation) dari segi perilaku sosial (social-behavioral), yang memberikan landasan etika moral bagi kehidupan bersama. 9) Kepemimpinan adalah penting, karena menyentuh fungsi-fungsi kepemimpinan manajemen dan administrasi, yang menjelaskan tentang status serta peran komponen Pemimpin, Manajer, Administrator dan orang yang dipimpin. 10) Kepemimpinan adalah penting, karena bertalian erat dengan faktor kontekstual-historikal, sebagai lokus dan situasi bagi penyelenggaraan upaya memimpin. 11) Kepemimpinan adalah penting, karena berhubungan dengan kerja dalam semua bentuk, aspek dan tingkatan (Tomatala, 2011).

Menguraikan hubungan kepemimpinan dengan Pemimpin berkualifikasi Human Capital 4.0, maka diskursus pada bagian ini, akan menyinggung tiga hal penting, yaitu: Pertama, Memaknai Kepemimpinan; Kedua, Tempat Pemimpin dalam Kepemimpinan; Ketiga, Kepemimpinan Global dan Pemimpin Human Capital 4.0 Abad XXI.

Pertama, Memaknai Kepemimpinan. Kepemimpinan dapat dimaknai dari sua sisi, yaitu makna kepemimpinan secara filofosis, dan praktis. Secara filosofis, "Kepemimpinan ialah 'suatu proses terencana yang dinamis, melalui suatu periode waktu dalam situasi (suatu atau berbagai situasi), yang di dalamnya PEMIMPIN menggunakan: Perilaku (pola dan atau gaya) kepemimpinan yang khusus dan sarana serta prasarana dan atau sumber-sumber $(9 \mathrm{M})$ kepemimpinan untuk memimpin (menggerakkan atau mempengaruhi) BAWAHAN (pengikutpengikut), guna melaksanakan tugas atau pekerjaan (menyelesaikan tugas), ke arah (dalam upaya pencapaian) tujuan yang menguntungkan (membawa keuntungan timbal balik) bagi Pemimpin, dan bawahan serta lingkungan sosial di mana organisasi berada' (Tomatala, 2011: 29-31). Dari sudut pandang praktis, "Kepemimpinan adalah SENI, yang didefinisikan dalam tujuh sisi, yaitu: 1) Seni Bekerjasama. 2) Seni Pemenuhan Kebutuhan. 3) Seni Penggalangan dan Pemaduan. 4) Seni Mempengaruhi atau Memimpin. 5) Seni Memerintah dan 
berkomunikasi. 6) Seni Membuat Peta Keinginan Masa Depan Organisasi (merencanakan dan mengorganisir). 7) Seni Mendayagunakan SDM dan semua sumber dalam menjalankan upaya memimpin.

Kedua, Tempat Pemimpin dalam Kepemimpinan. Telah diuraikan sebelumnya, bahwa peran Pemimpin sangatlah dibutuhkan dalam semua bentuk kepemimpinan. Alasan terpenting bagi prinsip ini adalah bahwa kepemimpinan dan Pemimpin berkaitan erat secara fungsional, dan sangat berkepentingan dengan keberhasilan organisasi. Dalam upaya menggapai tujuan keorganisasian, maka kepemimpinan organisasi apa pun sangat memerlukan adanya Pemimpin yang kompeten dengan jiwa entrepreneur dan berkualifikasi Human Capital 4.0 Leader, untuk memimpin.

Indikator dan kriteria Pemimpin kompeten dengan kualifikasi ini, antara lain adalah: 1) Pemimpin kompeten adalah orang yang berjiwa entrepreneur dengan integritas, kapasitas, dan kapabilitas andal. 2) Pemimpin kompeten adalah orang yang memiliki komitmen kuat kepada TUHAN Allah, organisasi dan pekerjaan dengan kualitas, ketaatan, disiplin, dan performa tinggi). 3) Pemimpin kompeten adalah orang yang andal memimpin dalam situasi normal mau pun dalam krisis, yang memiliki kriteria berikut: a) Pemimpin berjiwa entrepreneur dan visioner dengan visi, misi, dan fokus yang benar. b) Pemimpin harus berani berpikir, bersikap dan bertindak, dengan mencipta peluang untuk bertindak tangkas, tepat - cepat dalam memimpin. c) Pemimpin haruslah seorang pemikir unggul yang proaktif, kritis, kreatif, dan inovatif, inspiratif dan kontemplatif dengan wawasan serta keberanian berpikir, membuat keputusan dan bertindak unik untuk mencapai keberhasilan. d) Pemimpin kompeten haruslah orang yang berjiwa entrepreneur yang memiliki kemandirian dan kebebasan finansial untuk bebas melaksanakan upaya memimpin yang benar, baik, sehat optimal dan produktif. e) Pemimpin yang kompeten haruslah mempertahankan nilai kebersamaan, kesetiaan, dengan konsensus kerjasama tinggi meneguhkan organisasi untuk berkiprah mencapai keberhasilan. f) Pemimpin kompeten haruslah seorang individu dengan tingkat integritas etika - moralitas tinggi, demi melindungi organisasi, sehingga dapat berjalan langgeng. g) Pemimpin kompeten haruslah seorang individu yang memiliki norma dan etos kuat tentang kerja keras serta kerja cerdas. h) Pemimpin kompeten memiliki kuasa dan kekuatan untuk mengayomi, dan menjamin kepastian hidup yang dilakukan secara benar. i) Pemimpin kompeten adalah pribadi pencipta kondisi kondusif bagi kerja sama erat dan harmonis mewadahkan kerja organisasi yang dinamis. j) Pemimpin kompeten adalah pribadi yang tangguh, dengan kebanggaan mengabdi pada organisasi. k) Pemimpin kompeten adalah pribadi yang memiliki keandalan untuk meneguhkan harapan masa depan organisasi. k) Pemimpin kompeten adalah individu yang bermental investor kuat, yang dapat menyatukan semua komponen untuk bersinergi mewujudkan performa optimal yang efektif, efisien dan 
produktif. 1) Pemimpin kompeten adalah individu yang mempedulikan serta mementingkan kesejahteraan bersama. m) Pemimpin kompeten adalah pewaris nama dan kualitas dengan "branding sukses" karena pembuktian diri yang ajeg.

Ketiga, Kepemimpinan Global dan Pemimpin Human Capital 4.0. Menjelaskan tentang kepemimpinan global, John Nirenberg mengatakan bahwa "Kepemimpinan global merupakan elemen utama kesuksesan ... Para manejer (pemimpin) global dibentuk, bukan dilahirkan. Ini bukan sebuah proses alami. Kami adalah manusia-manusia yang dibentuk. ... dengan menjadi manajer (pemimpin) global, banyak hal yang bisa anda lakukan." (Nirenberg, 2003).

Ciri-ciri Pemimpin Global dengan Kapasitas Human Capital 4.0. Dalam kaitan penegasan Nirenberg di atas, dapat ditegaskan bahwa "Pemimpin global adalah pribadi kompeten yang berjiwa entrepreneur yang memiliki wawasan global, dengan kualifikasi Pemimpin Human Capital 4.0 (Human Capital 4.0 Leader). Pemimpin seperti ini andal berpikir global dan bertindak lokal, yang memiliki kemampuan menjalankan kepemimpinan dengan persuasi dan interaksi tinggi. Pemimpin dengan kemampuan seperti ini, andal memainkan peran sebagai katalis, koordinator, dan fasilitator yang menggerakkan inisiatif, mengakomodasi respon untuk performansi tinggi ke arah efektivitas, efisiensi dan keberhasilan kolektif. Indikator kemampuan Pemimpin berjiwa entrepreneur berwawasan global dengan kualifikasi Pemimpin Human Kapital 4.0 antara lain adalah: 1) Memiliki kemampuan mempengaruhi yang elegan bagi terwujudnya perubahan yang terbaik dan terkontrol, yang terjadi secara kondusif. 2) Memiliki kemampuan menciptakan hubungan kolegial bagi sinergi untuk kepentingan kemajuan bersama. 3) Memiliki kemampuan mengerakkan interasksi timbal balik atara komponen pemimpin dan orang yang dipimpin, bagi upaya kerja sinergis dan simultan, untuk pencapaian bersama demi kepentingan kemajuan organisasi. 4) Memiliki kemampuan mengindentifikasi praktek-praktek kepemimpinan terbaik bagi efektivitas, efisiensi, kesehatan, optimalisasi dan produktifitas upaya memimpin. 5) Memiliki kemampuan mempertajam ketrampilan dan penyebaran SDM pada semua lini yang dapat berperan secara maksimal memberi pendukungan kerja lintas sektor. 6) Memiliki kemampuan menempatkan diri sebagai mitra dalam menerapkan kuasa kepemimpinan demi mewujudkan performa berkualitas dalam organisasi. 7) Memiliki kemampuan memobilisasi para kolega untuk berperan secara kolektif dan simultan mencapai keberhasilan bersama. 8) Memiliki kemampuan penyesuaian kepada perubahan pada setiap tahap, yang membantu organisasi mencapai visinya dalam segala kondisi. 9) Memiliki kemampuan membangun relasi dan jejaringan positif bagi keberhasilan kerja, dengan membangun kemitraan yang luas secara besinambung antara organisasi, karyawan dan konsumer bagi kemanfaatan serta keuntungan bersama (Nirenberg, 2003). 10) Memiliki kemampuan memanfaatkan human intelligence

27 | Komitmen Mahasiswa Manajemen Pendidikan Kristen dalam..., Tomatala, Yakob Jurnal Christian Humanioran | http://e-journal.iakntarutung.ac.id/index.php/humaniora 
dan artiticial intelligence dengan teknonogi canggih guna mewujudkan kepemimpinan yang relevan pada Abad XXI.

Karakteristik Pemimpin Global dengan Kapasitas Human Capital 4.0 untuk Abad XXI (Tomatala, 2019). Seperti telah diuraian, dapat dikatakan bahwa Pemimpin Global dengan kualifikasi Human Capital 4.0 Leader adalah jawaban bagi tantangan perubahan yang diakibatkan oleh adanya disrupsi peradaban dan kemajuan industri dengan skala 4.0. Ada delapan karakteristik Pemimpin Global yang dapat dikemukakan di sini.

Satu, HC 4.0 adalah Dasar Pertumbuhan Ekonomi sebagai kunci bagi setiap kemajuan. Dalam kaitan ini, konsep HC 4.0 yang menempatkan "manusia" sebagai "pusat inventasi dan produksi" yang merupakan dasar bagi "pertumbuhan ekonomi" sebagai kunci untuk membawa "kesejahteraan masyarakat." Berdasarkan pandangan Adam Smith, dasar bagi Pertumbuhan Ekonomi, dibangun di atas empat modal fix utama, yaitu: 1) Mesin (teknologi); 2) bangunan (infrastruktur); 3) tanah (materi); dan 4) abilitas (potensi dan atau kapasitas) anggota masyarakat dengan "talenta tak terbatas (Burhanudin, 2012). Semua landasan ini adalah potensi ekonomi yang dapat dimanfaatkan bagi pemberdayaan Human Capital 4.0".

Dua, HC 4.0 adalah instrumen bagi pengembangan Angkatan Kerja. Gagasan HC 4.0 melihat "Manusia dengan talenta tak terbatas sebagai Human Capital yang dapat dikembangkan menjadi "angkatan kerja" yang andal. Human capital sebagai angkatan kerja andal ini adalah kekuatan mengelola investasi dan produktivitas, yang dilakukan melalui pendekatan "cohort" (unit, force, contingent, group) guna memaksimalkan pelipatgandaan kuantitas, kualitas dan optimalisasi produksi. Human capital yang andal sebagai "modal manusia" adalah kekuatan untuk mengambil peran, meningkatkan serta mengoptimalkan produk ekonomi, bagi kesejahteraan umat manusia" (Burhanudin, 2012).

Tiga, Model Kepemimpinan dan Pemimpin Human Capital 4.0 menekankan pada pendekatan "Human Being Empowerment" (HBE). Pendekatan Human Being Empowerment (HBE) ini memperhitungkan aspek "sustainability" (keberlangsungan yang bertahan dan meningkat secara konsisten), meresponi disrupsi peradaban Abad XXI. Pendekatan HBE menempatkan peran SDM sebagai Social Entrepreneur yang memiliki potensi beyond competency, dan bidang usaha sebagai Social Entreprice yang merupakan upaya menjawab tantangan "Revolusi Teknologi 4.0 - 5G" dan Revolusi Industri 4.0. Fokus dari pengembangan berdasarkan konsep HBE ini adalah meneguhkan "kompetensi lebih" dari komponen human capital dengan human intelligence yang tinggi, untuk memanfaatkan kelebihan teknologi kekinian dengan artificial intelligence canggih, yang dimanfaatkan mengelola investasi dan produksi guna menghadirkan keberhasilan yang berdampak sosial luas serta membawa sejahtera bagi masyarakat banyak.

28 | Pemimpin Human Capital 4.0 dan Kepemimpinan Global..., Tomatala, Yakob Jurnal Christian Humanioran | http://e-journal.iakntarutung.ac.id/index.php/humaniora 
Peran dan pendekatan SDM HC 4.0 HBE yang mengembangkan serta menempatkan SDM dengan peran sebagai "social entrepreneur"dan bidang usaha sebagai "social entreprice" diharapkan akan membawa dampak sosial positif bagi organisasi serta lingkungan guna meresponi "Disrupsi Peradaban" (Civilization Disruptions) dengan Revolusi Teknologi 5.0 dan Industri 4.0.

Empat, Peran dan pendekatan SDM HC 4.0 HBE didasarkan atas prinsipprinsip berikut: 1) HBE HC 4.0 adalah respon atas disrupsi peradaban dengan kecanggihan IT, AI, robotik, teleportasi, sains baru, dsb; mendukung "Revolusi Industri 4.0" yang melipatgandakan investasi, interaksi lintas sektor, sinergi, aplikasi teknologi yang menghasilkan akselerasi produk ekonomi. 2) HBE HC 4.0 memberi tekanan bagi "konsistensi mencipta perubahan positif dalam investasi dan produksi secara sistemik," memanfaatkan teknologi canggih mewadahkan sinergi, guna memberi "jawaban ekstra cerdas" terhadap tantangan perubahan dan turbulensi sosial sebagai dampak dari disrupsi peradaban (Tomatala, 2019).

Lima, Unsur-unsur HBE HC 4.0 yang menentukan peran kepemimpinan melibatkan faktor berikut: 1) Budaya dan Perilaku Organisasi. Budaya dan perilaku organisasi melibatkan perilaku Pemimpin, dan perilaku bawahan berbasis sistem organisasi canggih yang lugas dan responsif, dengan "gaya kompetitif tinggi." Budaya dan perilaku organisasi berkualitas adalah sebagai dasar bagi efektifitas, efisiensi dan produktivitas investasi dan produksi ekonomi, yang berdampak sosial sistemik dan luas, guna menghadirkan sejahtera secara merata dalam masyarakat di mana organisasi berada. 2) Budaya dan Perilaku Kerja HBE HC 4.0 dalam kepemimpinan. Budaya dan perilaku kerja dalam kepemimpinan menyentuh aspek-aspek dasar yang berikut: a) Melengkapi komponen manusia sebagai HC 4.0 yang dikembangkan menjadi "lebih dari kompeten (beyond competent) dan pas atau sesuai bagi tugas (fit to the job)" sehingga dapat berkiprah dalam mewujudkan kerja kepemimpinan dengan kapasitas serta kapabilitas lebih. b) Kompetensi dan kesesuaian kualitas SDM HC bagi tugas ini ditandai unsur Etika Moral Tinggi sebagai landasan bagi kualitas mental SDM yang selalu terfokus kepada mengerjakan hal utama dan yang terbesar bagi kepentingan organisasi, yang menempatkan human intelligence sebagai faktor penentu keberhasilan. Kapasitas inteligensia ini nampak pada SDM HC yang andal memanfaatkan artificial intelligence (teknologi) dalam mewujudkan kerja secara cerdas (kritis, kreatif, inovatif, inspiratif, dan kontemplatif didukung ketrampilan Sosial, Ekonomi, Enprepreneur, dan Teknis yaitu ketrampilan menerapkan Kepemimpinan, Manajemen, Administrasi, yang diterapkan secara tepat guna dalam mewujudkan upaya memimpin yang unggul serta bersaing, sehingga kepemimpinan menjadi efektif, efisien sehat, optimal dan produktif.

Enam, Karakteristik Pemimpin HC 4.0 HBE ditandai keunggulan kualitas yang andal dalam bersaing. Keunggulan karakteristik kualitas ini adalah tepat

$29 \mid$ Komitmen Mahasiswa Manajemen Pendidikan Kristen dalam ..., Tomatala, Yakob

Jurnal Christian Humanioran | http://e-journal.iakntarutung.ac.id/index.php/humaniora 
untuk menjawab tantangan Abad XXI, yang ditandai kebiasaan, sikap, sifat, cara, mentalitas, dan perilaku kerja berkualitas serta bersaing. Keunggulan karakteristik HBE HC 4.0 tersebut antara lain adalah: 1) Agility: SDM Human Capital yang memiliki kebiasaan unggulan, yaitu "ability to move quickly and easy" (tangkas, tanggap, dan gesit, proaktif, antisipatif); 2) Flexibility: SDM Human Capital yang memiliki sikap "limberness (flexible, resilient) with range of motions" (keterbukaan); 3) Cross Mobility: SDM Human Capital yang memiliki gerak kerja dengan "Quality of being mobile" (keandalan gerak lintas sektor dalam organisasi yang bergerak dinamis); 4) Collaboration: SDM Human Capital yang memiliki cara kerja yang merupakan "action of joint working for productivity", sehingga ada upay aberbagi otoritas, dan sumber pendung untuk bergerak bersama; 5) Grit Mentality: SDM Human Capital yang memiliki karakter dan mentalitas kerja keras (hard works mentality) yang bekerja secara terfokus, yang diwujudkan secara konsisten oleh semua komponen Human Capital; 6) Meritocracy: SDM Human Capital yang diberi otoritas, status atau peran berlandasakan bukti kinerja berdasarkan falsafah "holding of power based on ability" (memiliki kuasa memimpin berbasis pencapaian) di mana kepemimpinan lebih menekankan pada penghargaan atas prestasi dan memberi kredit bagi setiap pekerja untuk gebrakan kerja yang sukses.

Tujuh, Keandalan Pemimpin HC 4.0 HBE merekayasa perilaku terencana. Pemimpin andal merekayasa dasar bagi perlaku kerja terencana dengan memanfaatkan "pilihan investasi dan pendekatan kerja berbasis teknologi kontemporer" yang pas dengan situasi dan kekuatan organisasi serta kondisi masyarakat kekinian, menyentuh peluang-peluang pilihan yang terbuka. Pemimpin dalam kaitan ini, andal menerapkan sistem manajemen berbasis Manajemen Kualitas Total (Total Quality Management - TQM), sebagai landasan bagi tulang punggung manajemen kepemimpinan organisasi. Dalam kaitan ini, proses dan tindakan kerja organisasi dimanajemeni dengan sikap terbuka dan gaya kepemimpinan "top down, bottom up, in side in" yang sesuai dengan kondisi organisasi, dalam upaya menggerakkan kerja menjawab tuntutan investasi dan produktivitas kinerja.

Delapan, Keandalan Pemimpin menerapkan perilaku kerja. Pemimpin HC 4.0 HBE andal menerapkan upaya kerja berbasis "Manajemen Performansi Tinggi" (High Performance Management - HPM). Penerapan HPM ini dieksekusi dengan menggunakan "Manajemen Strategi dan Taktik Memimpin" (Strategic and Tactical Management - STM) yang unggul, serta dibarengi pemanfaatan perangkat "teknologi ekonomi kekinian," di mana semua komponen human capital, dan semua sumber organisasi, semua perangkat teknologi informasi, infrastruktur, situasi kekinian, dsb., digunakan secara tepat, untuk menghadirkan kepemimpinan berkualitas, yang unggul dalam bersaing demi menggapai kesuksesan, menjawab tantangan Milenium XXI.

30 | Pemimpin Human Capital 4.0 dan Kepemimpinan Global..., Tomatala, Yakob Jurnal Christian Humanioran | http://e-journal.iakntarutung.ac.id/index.php/humaniora 


\section{KESIMPULAN DAN SARAN}

Sangatlah disadari bahwa kepemimpinan pada era milenial dalam dunia global dihadapkan pada disrupsi peradaban dengan kekuatan teknologi super canggih yang mengubah kondisi dunia secara sangat cepat, pesat, drastis, dan ekstra dinamis. Meresponi situasi ini, maka sangatlah diperlukan adanya Kepemimpinan dan Pemimpin yang berwawasan global dengan kualifikasi Human Capital 4.0 untuk memimpin organisasi dan generasi milenial secara pas pada Abad XXI.

Dalam menghadirkan Pemimpin Human Capital 4.0 HBE dan Kepemimpinan Global di Era Milenial, maka telah diketengahkan dua pokok percakapan, antara lain yaitu: Pertama, Pemimpin Kompeten Berjiwa Entrepreneur; Kedua, Kepemimpinan Global Human Capital 4.0 dalam Era Milenial. Kebenaran tentang Pemimpin dan kepemimpinan Global yang pas pada Abad XXI bagi generasi milenial ini menegaskan bahwa sangatlah dibutuhkan adanya Pemimpin kompeten yang berjiwa entrepreneur dengan kualifikasi Pemimpin Human Capital 4.0 HBE yang berkarakter mandiri, dengan visi besar, keberanian berpikir, keberanian bersikap serta keberanian bertindak secara jenius ditunjang mentalitas investor dan kebebasan finansial, untuk mengerjakan tanggung jawab kepemimpinan secara strategis taktis demi mencapai keberhasilan. Pemimpin HC 4.0 HBE memiliki kompetensi yang melibatkan: 1) Kompetensi integritas karakter (SQ), sebagai dasar otoritas dan kekuatan untuk memimpin dalam segala situasi. 2) Kompetensi kapasitas pengetahuan (IQ), yang menjelaskan adanya pengetahuan yang komprehensif dan khas lebih sebagai pemikir unggul dengan daya kritis, kreatif, inovati, inspiratif dan kontemplatif, dalam mengembangkan dan menangani tanggung jawab kepemimpinan. 3) Kompetensi kapabilitas kecakapan (SEETQ), meliputi aspek sosial, entrepreneur, ekonomi, teknis kepemimpinan, manajemen dan administrasi. Kompetensi kapabilitas ini memberikan keadalan memanfaatkan human intelligence, human skills dan artificial intelligence, untuk menjalankan upaya memimpin secara efektif, efisien, sehat, optimal, produktif dan sukses.

\section{DAFTAR PUSTAKA}

1976. International Dictionary of English Language.

1976. Webster New Universal Dictionary of The English Language. New York: Webster International Press.

Bass, B. M. 1981. Stogdils Handbook of Leadership. New York: The Free Press.

Bennis, W. 1994. Menjadi Pemimpin Efektif. Jakarta: Elex Media Komputindo.

Buchard, B. 2002. The Charge. Jakarta: Gramedia Pustaka Utama.

Burhanudin, M. 2012. Dari Personalia hingga Human Capital. (alvinburhani.wordpress.com).

31 | Komitmen Mahasiswa Manajemen Pendidikan Kristen dalam ..., Tomatala, Yakob

Jurnal Christian Humanioran | http://e-journal.iakntarutung.ac.id/index.php/humaniora 
Darmaputera, E. 2005. Pemimpin yang Memimpin. Jakarta: Kairos.

e-Sword Bible Commentary and Dictionary.

Gifford, J. 2018. 100 More Leadership Ideas. Surabaya: MIC Publishing.

Ken Shelton, Editor. 2004, New Paradigm of Leadership. Jakarta: Church Resource Ministry.

Nasokhili GIawa, Editor.2017. Kepemimpinan Kristen yang Membumi. Jakarta: YT Leadership Foundation dan STT Jaffray Jakarta.

Nirenberg, J. 2003. Kepemimpinan Global. Jakarta: Prestasi Pustaka Publisher.

Sarosa, p. 2005. Becoming Young Entrepreneur. Yogyakarta: Dolphin Books.

Tomatala, Y. 2002. Manajemen Pengembangan Sumberdaya Manusia Pemimpin Kristen. Jakarta: YT Leadership Foundation.

Tomatala, Y. 2010. Spiritual Entrepreneur. Jakarta: YT Leadership Foundation.

Tomatala, Y. 2011. Kepemimpinan yang Dinamis. Jakarta: YT Leadership Foundation.

Yakob Tomatala, Marthin Billa: Pemimpin Visioner Transformator Futuristik. (Jakarta: YT Leadership Foundation), 2012.

Tomatala, Y. 2018. Pengembangan Kompetensi dan Profesionalisme Guru Etika Kristen, Seminar Guru Agama Kristen SMTK Kementerian Agama RI. (Makassar: Hotel Golden Tulip Essential).

Tomatala, Y. 2019. Human Capital 4.0: Biblical Principles for Developing Human Capital Oriented Leadership. Jakarta: YT Leadership Foundation.

Tomatala, Y. 2019. How to Become a Successful Christian Entrepreneur. Jakarta: YT Leadership Foundation. 